\title{
Is There Enough Evidence for the Association of GN $\beta 3$ C825T Polymorphism With Functional Dyspepsia and Irritable Bowel Syndrome?
}

TO THE EDITOR: I read with great interest the paper from the Kim et $\mathrm{al}^{1}$ on the G-protein beta3 subunit (GN $\beta 3$ ) C825 T polymorphism with overlap syndrome of functional dyspepsia (FD) and irritable bowel syndrome (IBS) which demonstrated that no apparent association of the GN $\beta 3$ C825T polymorphism with FD, IBS or the overlap of FD and IBS existed. However, a recent study on Korean children showed the CC genotype of GN $\beta 3$ C 825 T may be associated with FD and diarrhea predominant IBS and the TT genotype might be associated with constipation predominant IBS. ${ }^{2}$ Since the first study ${ }^{3}$ from Germany which indicated homozygous GN $\beta 3$ 825CC genotype was associated with unexplained predominantly upper abdominal symptoms, many studies ${ }^{4-13}$ around the world showed inconsistent results on the association between the GN $\beta 3$ C825T polymorphism and functional gastrointestinal disorders (FGIDs). Many factors including heterogeneity of the disease, sample size, sample selection or racial difference may have contributed to these conflicting results. Still, we need to perform further large-scaled well-controlled studies to clarify this unresolved issue.

The GN 33 C825T polymorphism may change gastrointestinal motor and sensory functions through intracellular signal transduction and biological activity. Camilleri et $\mathrm{al}^{14}$ showed that GN $\beta 3$ T allele was associated with lower fasting gastric volume, which was one of the factors that predicted a portion of the variance in the symptoms of patients with dyspepsia. ${ }^{15}$ Further physiologic studies that deal with the effect of the GN 33 C825T polymorphism on gastrointestinal motor and sensory functions are necessary to clarify the pathophysiologic mechanism in which genetic variations contribute to gastrointestinal symptoms.

Can the GN $\beta 3$ C825T polymorphism influence response to therapy in FGIDs? Camilleri et $\mathrm{al}^{16}$ recently showed that GN $\beta 3$ TC/TT genotype might be associated with lower sensations of gas and urgency in response to rectal distention after clonidine treatment in humans. These findings could lead us to select FGIDs patients potentially treatable with clonidine and other drugs, based on genetic variation. Further pharamcogenetic studies could open a new horizon on treating patients with FGIDs in the future.

\section{Moo In Park \\ Department of Internal Medicine Kosin University College of Medicine, Busan, Korea}

1. Kim HG, Lee KJ, Lim SG, Jung JY, Cho SW. G-protein beta3 subunit $\mathrm{C} 825 \mathrm{~T}$ polymorphism in patients with overlap syndrome of functional dyspepsia and irritable bowel syndrome. J Neurogastroenterol Motil 2012;18:205-210.

2. Park CS, Uhm JH. Polymorphisms of the serotonin transporter gene and G-Protein $\beta 3$ subunit gene in Korean children with irritable bowel syndrome and functional dyspepsia. Gut Liver 2012;6:223228.

3. Holtmann G, Siffert W, Haag S, et al. G-protein $\beta 3$ subunit 825 CC genotype is associated with unexplained (functional) dyspepsia. Gastroenterology 2004;126:971-979.

4. Camilleri CE, Carlson PJ, Camilleri M, et al. A study of candidate genotypes associated with dyspepsia in a U.S. community. Am J Gastroenterol 2006;101:581-592.

5. van Lelyveld N, Linde JT, Schipper M, Samsom M. Candidate genotypes associated with functional dyspepsia. Neurogastroenterol Motil 2008;20:767-773.

6. Tahara T, Arisawa T, Shibata T, et al. Homozygous $825 \mathrm{~T}$ allele of the GNB3 protein influences the susceptibility of Japanese to dyspepsia. Dig Dis Sci 2008;53:642-646.

7. Andresen V, Camilleri M, Kim HJ, et al. Is there an association between GNB3-C825T genotype and lower functional gastrointestinal disorders? Gastroenterology 2006;130:1985-1994.

8. Oshima T, Nakajima S, Yokoyama T, et al. The G-protein beta3 subunit 825 TT genotype is associated with epigastric pain syndrome-like dyspepsia. BMC Med Genet 2010;11:13.

9. Lee HJ, Lee SY, Choi JE, et al. G protein beta3 subunit, interleukin-10, and tumor necrosis factor-alpha gene polymorphisms in Koreans with irritable bowel syndrome. Neurogastroenterol Motil 2010;22:758-763. 
10. Shimpuku M, Futagami S, Kawagoe T, et al. G-protein $\beta 3$ subunit $825 \mathrm{CC}$ genotype is associated with postprandial distress syndrome with impaired gastric emptying and with the feeling of hunger in Japanese. Neurogastroenterol Motil 2011;23:1073-1080.

11. Markoutsaki T, Karantanos T, Gazouli M, Anagnou NP, Ladas $\mathrm{SD}$, Karamanolis DG. Serotonin transporter and G protein beta 3 subunit gene polymorphisms in Greeks with irritable bowel syndrome. Dig Dis Sci 2011;56:3276-3280.

12. Saito YA, Locke GR 3rd, Zimmerman JM, et al. A genetic association study of 5-HTT LPR and GNbeta3 C825T polymorphisms with irritable bowel syndrome. Neurogastroenterol Motil 2007;19: 465-470.

13. Park HY, Jahng JH, Lee YJ, Park H, Lee SI. Serotonin transporter gene and G-protein beta3 C825 T gene polymorphism in patients with functional dyspepsia and irritable bowel syndrome. Korean J
Neurogastroenterol Motil 2009;15:58-64.

14. Camilleri M, Busciglio I, Carlson P, et al. Candidate genes and sensory functions in health and irritable bowel syndrome. Am J Physiol Gastrointest Liver Physiol 2008;295:G219-G225.

15. Delgado-Aros S, Camilleri M, Cremonini F, Ferber I, Stephens D, Burton DD. Contributions of gastric volumes and gastric emptying to meal size and postmeal symptoms in functional dyspepsia. Gastroenterology 2004;127:1685-1694.

16. Camilleri M, Busciglio I, Carlson P, et al. Pharmacogenetics of low dose clonidine in irritable bowel syndrome. Neurogastroenterol Motil 2009;21:399-410.

\section{Conflicts of interest: None.}

